\title{
FAKTOR-FAKTOR YANG BERHUBUNGAN DENGAN PRESTASI BELAJAR MAHASISWA POLTEKKES KEMENKES BANTEN SEMESTER I YANG MASUK MELALUI JALUR PMDP TAHUN $2012-2014$
}

\begin{abstract}
*Ahmad
Abstrak

Prestasi belajar merupakan salah satu indicator daya serap dan kecerdasan mahasiswa, yang dapat digunakan untuk menyusun dan menetapkan langkahlangkah kebijkan baik yang menyangkut mahasiswa, proses pendidikan maupun institusi pendidikan yang mengelola program pendidikan tersebut. Indikator yang menjadi tolok ukur prestasi belajar mahasiswa adalah perolehan prestasi.. Berdasarkan pengamatan penulis, dalam dua tahun terakhir ini, masih sering terungkap mahasiswa yang mengalami permasalahan yang berkaitan dengan prestasi belajar yang dibuktikan dengan perolehan prestasi yang masih rendah, masih adanya mahasiswa yang sering kali harus mengulang saat ujian akhir semester. Permasalahan tersebut terjadi juga pada mahasiswa yang masuk melalui jalur PMDP, padahal mahasiswa tersebut pada saat proses masuk, sudah menunjukan nilai prestasi belajar yang tinggi di sekolah asalnya.

Penelitian ini dilakukan guna memperoleh informasi factor yang berhubungan dengan prestasi belajar mahasiswa Poltekkes Kemenkes Banten semester I yang masuk melalui jalur PMDP tahun 2012 - 2014

Penelitian ini mengunakaan desain crosesctional study, dengan jumlah sampel sebanyak 60 mahasiswa yang masuk melalui jalur PMDP tahun 2012 - 2014. Data yang digunakan adalah data sekunder yang diperoleh dari bagian kemahasiswaan Poltekkes Kemenkes Banten bagian adak masing-masing jurusan.

Hasil penelitian menunjukkan sebagian besar mahasiswa semester I yang masuk melalui jalur PMDP memiliki prestasi belajar yang baik (70\%), sementara sebagian kecil lainnya memperoleh prestasi belajar kurang baik (30\%) Sebagian besar mahasiswa semester I yang masuk melalui jalur PMDP berasal dari sekolah negeri (76,7 \%) , Hampir seluruhnya mahasiswa semester I yang masuk melalui jalur PMDP berasal dari jenis sekolah SMA $(93,4 \%)$ Sebagian besar mahasiswa semester I yang masuk melalui jalur PMDP berjenis kelamin perempuan $(85 \%)$

Tidak ada hubungan antara asal sekolah, jenis sekolah dan jenis kelamin dengan perolehan prestasi belajar mahasiswa semester satu.

Perlunya melakukan telaahan lebih lanjut pada mahasiswa yang memperoleh IP semester I dibawah 3,00 terhadap perolehan nilai pada waktu belajar di SMA serta lembaga sekolah SMA asal mahasiswa tersebut
\end{abstract}

Kata kunci : prestasi belajar, indeks prestasi

*Poltekkes Kemenkes Banten 


\section{Pendahuluan}

Dalam perkuliahan mahasiswa dituntut untuk berkompetisi memperoleh prestasi belajar. Prestasi belajar merupakan salah satu indicator daya serap dan kecerdasan mahasiswa, yang dapat digunakan untuk menyusun dan menetapkan langkahlangkah kebijkan baik yang menyangkut mahasiswa, proses pendidikan maupun institusi pendidikan yang mengelola program pendidikan tersebut.

Indikator yang menjadi tolok ukur prestasi belajar mahasiswa adalah perolehan prestasi. Guna memperolah prestasi belajar mahasiswa yang baik, bukanlah suatu hal yang mudah, sebab banyak factor yang mempengaruhinya, diantaranya prestasi belajar mahasiswa sebelumnya, ketika mahasiswa masih bersekolah di tingkat Sekolah Lanjutan Tingkat Atas (SLTA) yang tercermin dalam rapot yang dimiliki mahasiswa.

Prestasi belajar sebelumnya ini terkait erat dengan asal sekolah para mahasiswa sebelum meraka masuk ke Poltekkes Kemenkes Banten
Poltekkes Kemenkes Banten sebagai salah satu pendidikan tinggi di Provinsi Banten memiliki harapan yang besar, agar para mahasiswanya memperoleh prestasi belajar yang baik.Salah satu upaya guna memperoleh calon mahasiswa yang memiliki prestasi yang baik tersebut, diawali dari peroses penerimaan mahasiswa baru, yang dapat menghasilkan calon mahasiswa baru dengan prestasi akademik yang baik, yaitu melalui system penerimaan mahasiswa baru melalui jalur.

Penelusuran Minat dan Prestasi (PMDP). Proses ini telah dilakukan Poltekkes Kemenkes Banten sejak tahun 2012 yang lalu.

Berdasarkan pengamatan penulis, dalam dua tahun terakhir ini, masih sering terungkap mahasiswa yang mengalami permasalahan yang berkaitan dengan prestasi belajar yang dibuktikan dengan perolehan prestasi yang masih rendah, masih adanya mahasiswa yang sering kali harus mengulang saat ujian akhir semester.

Permasalahan tersebut terjadi juga pada mahasiswa yang masuk melalui jalur PMDP, padahal 
mahasiswa tersebut pada saat proses masuk, sudah menunjukan nilai prestasi belajar yang tinggi di sekolah asalnya. Infromasi ini terungkap pada waktu rapat evaluasi di jurusan, baik keperawatan maupun analis kesehatan.

Berdasarkan uraian di atas, penulis tertarik untuk meneliti analisis factor - factor yang berhubungan dengan prestasi belajar mahasiswa Poltekkes Kemenkes Banten semester I yang masuk melalui jalur PMDP tahun 2012 2014.

Penelitian ini bertujuan untuk mengetahui proporsi prestasi belajar,asal sekolah, jenis asal sekolah, dan jenis kelamin mahasiswa Poltekkes Kemenkes Banten semester I yang masuk melalui jalur PMDP tahun 2012 2014, serta mengetahui hubungan asal sekolah, jenis asal sekolah dan jenis kelamin dengan prestasi belajar mahasiswa.

\section{Metodologi Penelitian}

Penelitian ini dilakukan di Poltekkes Kemenkes Banten, dengan desain Cross Sectional. Desain study
Cross Sectional ialah suatu penelitian untuk mempelajari dinamika korelasi antara faktorfaktor resiko dengan efek, dengan cara pendekatan, observasi atau pengumpulan data sekaligus pada suatu saat (point time approach). Data yang menyangkut variabel bebas ( variabel resiko ) dan variabel terikat ( variabel akibat ), akan dikumpulkan dalam waktu yang sama (Notoatmodjo, 2010 ). Alasan pemilihan desain study cross sectional karena mudah dilakukan, lebih ekonomis, dan hasilnya dapat diperoleh dengan cepat

Instrumen pengumpulan data yang digunakan pada penelitian ini adalah format pengumpulan data yang penulis susun guna menghimpun data sekunder yang ada di Program Studi di lingkungan Poltekkes Kemenkes Banten serta direktorat Poltekkes Kemenkes Banten

Populasi penelitian ini adalah seluruh mahasiswa yang tercatat di program studi Diploma III yang ada di Poltekkes Kemenkes Banten yang masuk melalui jalur PMDP mulai 
tahun 2012 - 2014 yang berjumlah 60 orang.

Pengumpulan data pada penelitian ini dilakukan dengan mengisi format pengumpulan data yang telah disusun oleh peneliti. Data yang digunakan adalah data sekunder berupa data karakteristik mahasiswa Prodi diploma III Poltekkes Kemenkes Banten yang masuk melalui jalur PMDP mulai tahun 2012 sampai dengan 2014 serta data perolehan indek prestasi yang diperoleh mahasiswa pada semester

Proses pengolahan data dilakukan melalui tahapan editing, coding, entery, dan tabulating. Selanjutnya data yang sudah diolah dilakukan analisis univariat dan bivariat.

\section{Hasil}

1. Jumlah Peserta PMDP dan jumlah sekolah peserta PMDP dan peserta uji tulis

\section{Grafik 1}

Distribusi Peserta Berdasarkan Sekolah dan Jalur Masuk (PMDP dan Uji Tulis) di Poltekkes Kemenkes Banten Tahun 2012 - 2014

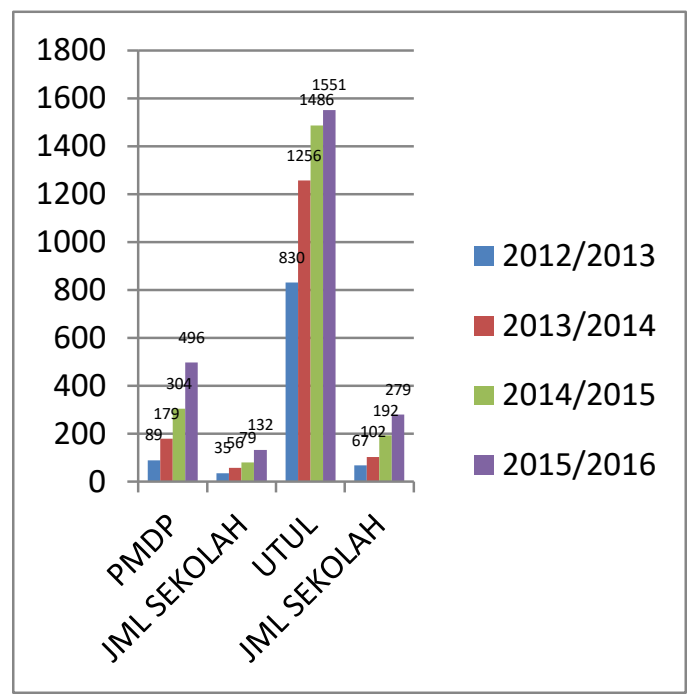

Pada grafik 1 terlihat bahwa jumlah peserta dan jumlah sekolah peserta PMDP Poltekkes Kemenkes Banten menunjukkan adanya peningkatan setiap tahunnya. Peningkatanya dalam satu tahun terakhir diatas 50 $\%$.

Sementara itu peserta uji tulis dan jumlah sekolah peserta uji tulis Poltekkes Kemenkes Banten menunjukan adanya peningkatan setiap tahunnya. Peningkatan peserta uji tulis maupun peningkatan peserta jumlah dalam dua tahun terakhir cenderung menurun, yakni sebesar $18 \%$ dan $4,4 \%$, peserta jumlah sekolah pendaftar uji tulis sebesar $88 \%$ dan $45 \%$. 
2. Rata - rata Prestasi (IP) Semester I

Grafik 2

Rata-rata Indeks Prestasi Mahasiswa semester I Pada Jurusan di Lingkungan Poltekkes Kemenkes Banten Tahun 2012 - 2014

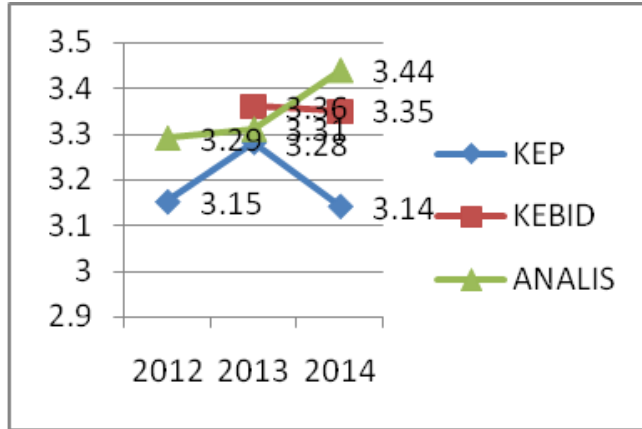

Pada grafik 2 terlihat bahwa rata - rata indeks prestasi mahasiswa jurusan keperawatan lebih rendah dibanding jurusan kebidanan dan analis kesehatan dalam tiga tahun terakhir

\section{Peserta PMDP}

\section{Grafik 3}

Jumlah Peserta PMDP berdasarkan Jurusan Di Lingkungan Poltekkes Kemenkes Banten Tahun 2012 2014

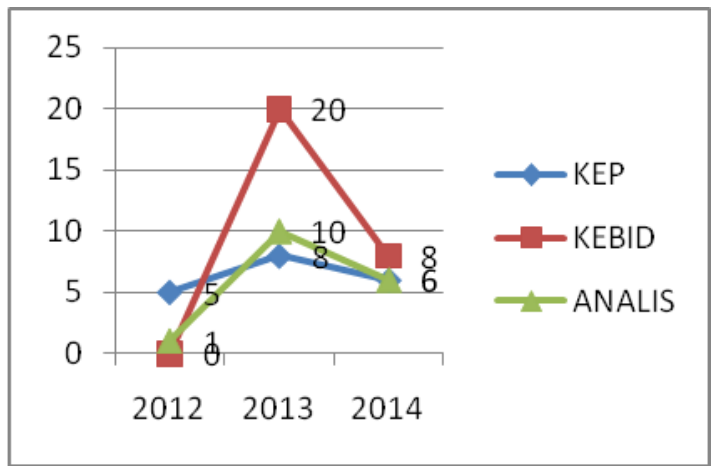

4. Prestasi Belajar Semester I

Tabel 1

Distribusi responden berdasarkan perolehan prestasi semester I Tahun akademik 2012/2013 s.d. $2014 / 2015$

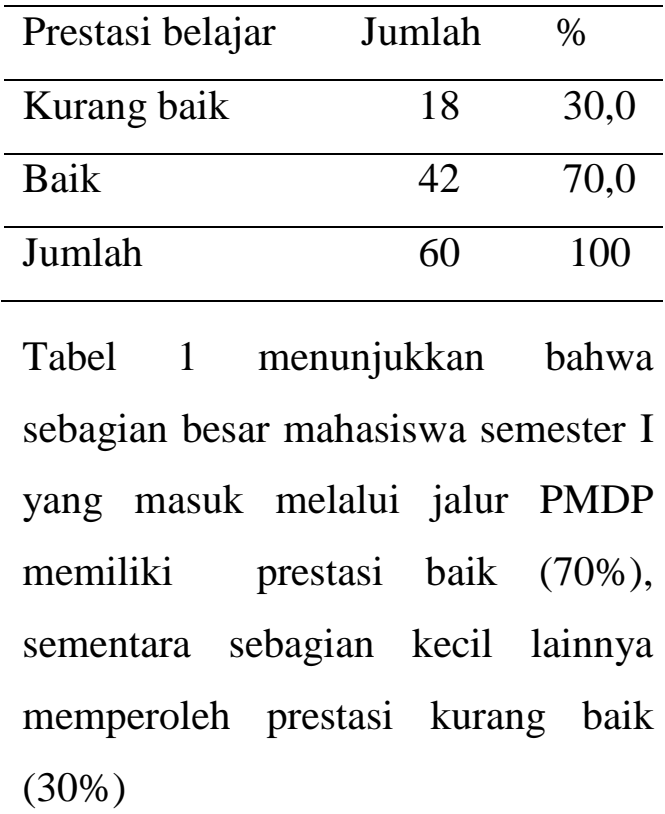

5. Prestasi Belajar Semester I

Tabel 2

Distribusi Mahasiswa Masuk

Melalui Uji Tulis

Berdasarkan Prestasi Smt I

T.A 2012/2013 s.d. 2014/2015

\begin{tabular}{lll}
\hline Prestasi belajar & Jumlah & $\%$ \\
\hline Kurang baik & 331 & 49,0 \\
Baik & 348 & 51,0 \\
\hline Jumlah & 679 & 100
\end{tabular}

Tabel 2 menunjukkan bahwa hampir setengahnya mahasiswa semester I yang masuk melalui jalur uji tulis memiliki prestasi kurang baik (49\%). 
Tabel 3

Distribusi Mahasiswa Masuk Melalui Uji Tulis Berdasarkan Prestasi Smt I Pada jurusan Keperawatan T.A 2012/2013 s.d. 2014/2015

\begin{tabular}{lll}
\hline Prestasi belajar & Jumlah & $\%$ \\
\hline Kurang baik & 146 & 45 \\
Baik & 182 & 55 \\
\hline Jumlah & 328 & 100 \\
\hline
\end{tabular}

Tabel 3 menunjukkan bahwa hampir setengahnya mahasiswa semester I yang masuk melalui jalur uji tulis memiliki prestasi kurang baik $(45 \%)$

Tabel 4

Distribusi Mahasiswa Masuk Melalui Uji Tulis Berdasarkan Prestasi Smt I Pada Jurusan Kebidanan T.A 2012/2013 s.d. 2014/2015

\begin{tabular}{lcc}
\hline Prestasi belajar & Jumlah & $\%$ \\
\hline Kurang baik & 73 & 53 \\
Baik & 64 & 47 \\
\hline Jumlah & 137 & 100 \\
\hline
\end{tabular}

Tabel 4 menunjukkan bahwa lebih dari setengahnya mahasiswa semester I yang masuk melalui jalur uji tulis memiliki prestasi kurang baik $(53 \%)$
Tabel 5

Distribusi Mahasiswa Masuk Melalui

Uji Tulis Berdasarkan Prestasi Smt I

Pada Jurusan Analis Kesehatan

T.A 2012/2013 s.d. 2014/2015

\begin{tabular}{lll}
\hline Prestasi belajar & Jumlah & $\%$ \\
\hline Kurang baik & 112 & 52 \\
Baik & 102 & 48 \\
\hline Jumlah & 214 & 100 \\
\hline
\end{tabular}

Tabel 5 menunjukkan bahwa lebih dari setengahnya mahasiswa semester I yang masuk melalui jalur uji tulis memiliki prestasi kurang baik $(52 \%)$.

\section{Asal sekolah}

Tabel 6

Distribusi Mahasiswa Smt I

Berdasarkan Asal Sekolah

T.A 2012/2013 s.d. 2014/2015 Asal Sekolah Jumlah \%

\begin{tabular}{lll}
\hline Swasta & 14 & 23,3 \\
Negeri & 46 & 76,7 \\
\hline Jumlah & 60 & 100 \\
\hline
\end{tabular}

Tabel 6 menunjukan bahwa sebagian besar mahasiswa semester I yang masuk melalui jalur PMDP berasal dari sekolah negeri $(76,7 \%)$ sementara sebagian kecil lainnya berasal dari sekolah swasta $(23,3 \%)$ 
7. Jenis sekolah

\section{Tabel 7}

Distribusi Mahasiswa Berdasarkan Jenis Sekolah

T.A 2012/2013 s.d. 2014/2015

\begin{tabular}{lcc}
\hline Jenis Sekolah & Jumlah & $\%$ \\
\hline MA & 4 & 6,7 \\
SMA & 56 & 93,4 \\
\hline Jumlah & 60 & 100 \\
\hline
\end{tabular}

Tabel 7 menunjukan bahwa hampir seluruhnya mahasiswa semester I yang masuk melalui jalur PMDP berasal dari jenis sekolah SMA $(93,4 \%)$ sementara sebagian kecil lainnya berasal dari jenis sekolah Madrasah Aliyah (6,7\%)

\section{Jenis kelamin}

Tabel 8

Distribusi responden berdasarkan jeis kelamin mahasiswa semester I Tahun akademik 2012/2013 s.d. $2014 / 2015$

\begin{tabular}{lll}
\hline Jenis kelamin & Jumlah & $\%$ \\
\hline Laki-laki & 9 & 15 \\
Perempuan & 51 & 85 \\
\hline Jumlah & 60 & 100
\end{tabular}

Tabel 8 menunjukan bahwa sebagian besar mahasiswa semester I yang masuk melalui jalur PMDP berjenis kelamin perempuan $(85 \%)$, sementara sebagian kecil lainnya berjenis kelamin laki-laki (15\%)

9. Hubungan asal sekolah dengan perolehan prestasi belajar

Tabel 9

Distribusi Mahasiswa PMDP Smt I Berdasarkan Asal Sekolah dan Prestasi Belajar Di Poltekkes Kemenkes Banten T.A 2012 / 2013 s.d. 2014/2015

\begin{tabular}{lcccccc}
\hline \multirow{2}{*}{$\begin{array}{l}\text { Asal } \\
\text { Sekolah }\end{array}$} & \multicolumn{4}{c}{ Prestasi belajar } & \multirow{2}{*}{ Semester I } & Jumlah \\
\cline { 2 - 5 } & $\begin{array}{c}\text { Kurang } \\
\text { baik }\end{array}$ & \multicolumn{2}{c}{ Baik } & & \\
\cline { 2 - 6 } & $\mathrm{F}$ & $\%$ & $\mathrm{f}$ & $\%$ & $\mathrm{f}$ & $\%$ \\
\hline Swasta & 5 & 55.6 & 4 & 44.4 & 9 & 100 \\
Negeri & 13 & 25.5 & 38 & 74.5 & 51 & 100 \\
\hline Jumlah & 18 & 30 & 42 & 70 & 60 & 100 \\
\hline \multicolumn{7}{c}{$P v=0,39$} \\
\hline
\end{tabular}

Tabel 9 menunjukkan bahwa prestasi semester I, mahasiswa Poltekkes Kemenkes Banten yang masuk melalui jalur PMDP yang kurang baik, proporsinya lebih tinggi terjadi pada mahasiswa yang berasal dari sekolah swasta (42,9\%) dibanding mahasiswa yang berasal dari sekolah negeri $(26,1 \%)$.

Hasil uji statistic kai-kuadrat pada alpha 0,05 diperoleh nilai $\mathrm{p}$ $=0,39(\mathrm{p}>\alpha)$ yang berarti bahwa secara statistic tidak ada hubungan 
bermakna antara asal sekolah dengan perolehan prestasi semester I mahasiswa Poltekkes Kemenkes Banten yang masuk melalui jalur PMDP.

10. Hubungan jenis sekolah dengan prestasi belajar

Tabel 10

Distribusi Mahasiswa PMDP Smt I

Berdasarkan Jenis Sekolah dan

Prestasi Belajar Di Poltekkes

Kemenkes Banten

T.A 2012 / 2013 s.d. 2014/2015

\begin{tabular}{ccccccc}
\hline \multirow{2}{*}{$\begin{array}{c}\text { Jenis } \\
\text { Sekolah }\end{array}$} & \multicolumn{4}{c}{ Prestasi belajar } & \multirow{2}{*}{ Semester I } & Jumlah \\
\cline { 2 - 5 } & $\begin{array}{c}\text { Kurang } \\
\text { baik }\end{array}$ & \multicolumn{2}{c}{ Baik } & & \\
\cline { 2 - 6 } & $\mathrm{f}$ & $\%$ & $\mathrm{f}$ & $\%$ & $\mathrm{f}$ & $\%$ \\
\hline MA & 1 & 25 & 3 & 75 & 4 & 100 \\
SMU & 17 & 30 & 39 & 69 & 56 & 100 \\
\hline Jumlah & 18 & 30 & 42 & 70 & 60 & 100 \\
\hline \multicolumn{7}{c}{$P v=1,00$} \\
\hline
\end{tabular}

Tabel 10 menunjukkan bahwa prestasi semester I, mahasiswa Poltekkes Kemenkes Banten yang masuk melalui jalur PMDP yang kurang baik, proporsinya lebih tinggi terjadi pada mahasiswa yang berasal dari jenis sekolah SMA (30,4\%) dibanding mahasiswa yang berasal dari sekolah Madrasah Aliyah(25\%).
Hasil uji statistic kai-skuer pada alpha 0,05 diperoleh nilai $\mathrm{p}$ $=1,00(p>\alpha)$ yang berarti bahwa scara statistic tidak ada hubungan bermakna antara jenis sekolah dengan perolehan prestasi semester I mahasiswa Poltekkes Kemenkes Banten yang masuk melalui jalur PMD

11. Hubungan jenis kelamin dengan prestasi belajar

\section{Tabel 11}

Distribusi Mahasiswa PMDP Smt

I Berdasarkan Jenis kelamin dan Prestasi Belajar Di Poltekkes

Kemenkes Banten T.A 2012 / 2013 s.d. 2014/2015

\begin{tabular}{lcccccc}
\hline \multirow{2}{*}{$\begin{array}{c}\text { Jenis } \\
\text { Kelamin }\end{array}$} & \multicolumn{3}{c}{ Prestasi belajar } \\
\cline { 2 - 6 } & $\begin{array}{l}\text { Kurang } \\
\text { baik }\end{array}$ & \multicolumn{3}{c}{ Baik } & & \\
& F & $\%$ & $\mathrm{f}$ & $\%$ & $\mathrm{~F}$ & $\%$ \\
\hline Laki-laki & 5 & 55.6 & 4 & 44.4 & 9 & 100 \\
Perempuan & 13 & 25.5 & 38 & 74.5 & 51 & 100 \\
\hline Jumlah & 18 & 30 & 42 & 70 & 60 & 100 \\
\hline \multicolumn{6}{c}{$P v=0,156$} \\
\hline
\end{tabular}

Pada tabel 11 menunjukkan bahwa prestasi semester I, mahasiswa Poltekkes Kemenkes Banten yang masuk melalui jalur PMDP yang kurang baik, proporsinya lebih tinggi terjadi pada mahasiswa yang berjenis kelamin 
laki-laki $\quad(55,6 \%) \quad$ dibanding mahasiswa yang berjenis kelamin perempuan $(25,5 \%)$.

Hasil uji statistic kai-skuer pada alpha 0,05 diperoleh nilai $\mathrm{p}=$ $0,156(p>\alpha)$ yang berarti bahwa scara statistic tidak ada hubungan antara jenis kelamin dengan perolehan prestasi semester I mahasiswa Poltekkes Kemenkes Banten yang masuk melalui jalur PMDP

\section{Pembahasan}

\section{Prestasi Belajar Mahasiswa}

Hasil penelitian menunjukan bahwa sebagian besar mahasiswa semester I yang masuk melalui jalur PMDP memiliki prestasi belajar yang baik (70\%), sementara sebagian kecil lainnya memperoleh prestasi belajar yang kurang baik (30\%). Gambaran ini menunjukan bahwa Mahasiswa yang masuk melalui jalur PMDP, memiliki kemampuan yang baik dalam belajar.

Sebagian kecil mahasiswa yang masih memiliki prestasi yang kurang baik, sebenarnya juga memiliki indeks prestasi diatas 3,00, namun karena hasil ukur yang digunakan peneliti untuk Indeks Prestasi (IP) semester I yang kurang baik cukup tinggi, yaitu jika dibawah rata-rata IP semester I $(3,2)$, maka sebagian kecil mahasiswa termasuk memiliki prestasi belajar yang kurang.

Data yang ada juga menunjukan ada satu mahasiswa yang memiliki indeks prestasi semester I dibawah 3.00 pada jurusan keperawatan. Proporsi mahasiswa jalur PMDP yang memiliki IP semester I yang dibawah rata-rata, relative sedikit, namun demikian perlu menjadi bahan pertimbangan dalam menetapkan kriteria calon mahasiswa yang masuk melalui jalur PMDP memiliki peringkat prestasi akademik di kelasnya masuk ranking 1 sampai 5.

Perolehan prestasi belajar yang kurang baik tersebut, mungkin berkaitan dengan factor internal mahasiswa terutama berkaitan dengan kemampuan adaptasi proses belajar maupun pengenalan materi kuliah khususnya yang berkaitan dengan bidang profesinya serta minat dan motivasi belajar mahasiswa, 
Sementara itu pada analisis indeks prestasi mahasiswa semester I yang masuk melalui uji tulis, menunjukan bahwa perolehan prestasi yang kurang baik proporsinya lebih tinggi dibanding mahasiswa yang masuk melalui jalur PMDP. Pada mahasiswa yang masuk melalui jalur uji tulis hampir setengahnya (49 \%) mahasiswanya memperoleh indeks prestasi kurang baik (dibawah rata-rata kelompoknya). Hal ini menunjukkan bahwa mahasiwa yang masuk melalui jalur PMDP memiliki kemampuan lebih baik dalam belajarnya dibanding mahasiswa yang masuk melalui jalur uji tulis.

Data rata - rata perolehan indeks prestasi mahasiswa semester satu di lingkungan Poltekkes Kemenkes Banten sejak tahun 2012 sampai dengan 2014, menunjukan peningkatan setiap tahunnya. Pada tahun 2012 rata - rata indeks prestasi semester satu 3,15, meningkat menjadi 3,31 pada tahun 2013 dan 2014. Rata - rata perolehan indeks prestasi tertinggi dicapai oleh mahasiswa tingkat satu jurusan Analis Kesehatan dan indeks prestasi terendah terdapat pada mahasiswa tingkat satu jurusan keperawatan.

Perolehan indeks prestasi ini kiranya berkaitan dengan jumlah pendaftar yang masuk ke masingmasing jurusan dan tingkat keketatan dalam seleksi masuk di masingmasing pendaftar. Sampai dengan tahun 2015, kecenderungan jumlah pendaftar dan jumlah asal sekolah yang mendaftar ke Poltekkes Kemenkes Banten terus menunjukan peningkatan baik pada jalur PMDP maupun jalur uji tulis. Jumlah pendaftar jalur PMDP meningkat sejak tahun 2012 hingga 2015 di atas $63 \%$ setiap tahun dengan rata-rata peningkatan selama tiga tahun terakhir sebesar $78 \%$, sementara sekolah yang siswanya mendaftar melalui jalur PMDP juga menunjukan peningkatan dengan rata-rata $56 \%$ dalam tiga tahun terakhir. Jumlah pendaftar jalur uji tulis menunjukan peningkatan dalam tiga tahun terakhir dengan rata-rata $24 \%$, namun demikian jika dicermati prosentase peningkatannya menunjukan penurunan dalam tiga tahun terakhir. 


\begin{tabular}{lrrll}
\multicolumn{1}{c}{ Pada } & tahun & 2015 & jalur PMDP sebagian besar memiliki \\
peningkatannya & hanya & 4,4 & $\%$ & prestasi belajar yang baik, maka \\
dibanding tahun 2014. Sementara itu & perlu terus dikembangkan proses \\
jumlah sekolah yang siswanya & rekruitmen mahasiswa malalui jalur \\
mendaftar melalui uji tulis & ini.
\end{tabular}

mengalami peningkatan dalam tiga tahun terakhir sebesar $62 \%$, namun demikian terlihat adanya kecenderungan penurunan prosentase peningkatannya dalam satu tahun terakhir. keadaan ini hendaknya menjadi perhatian bagi Poltekkes Kemenkes Banten, mengingat sebagai satu-satunya institusi penidikan kesehatan milik pemerintah di Provinsi Banten, diharapkan dapat menjadi pilihan pertama dan utama bagi para lulusan SLTA di wilayah Provinsi Banten, jika mereka berminat untuk menjadi profesi di bidang kesehatan khususnys perawat, bidan dan analis kesehatan, sehingga kecenderungan penurunan prosentase jumlah pendaftar maupun jumlah sekolah yang siswanya mendaftar di Poltekkes Kemenkes Banten tidak terjadi.

Memperhatikan hasil perolehan prestasi belajar semester I pada mahasiswa yang masuk melalui

2. Hubungan asal sekolah dengan prestasi belajar

Hasil penelitian menunjukkan bahwa prestasi belajar semester I, mahasiswa Poltekkes Kemenkes Banten yang masuk melalui jalur PMDP yang kurang baik, proporsinya lebih tinggi terjadi pada mahasiswa yang berasal dari sekolah swasta $(42,9 \%)$ dibanding mahasiswa yang berasal dari sekolah negeri $(26,1 \%)$.

Gambaran ini menunjukkan bahwa siswa yang berasal dari sekolah swasta yang memiliki prestasi belajar kurang proporsinya hampir dua kali lipat dibanding yang berasal dari sekolah negeri. Kondisi ini mungkin berkaitan dengan perbedaan dalam menentukan standar nilai mata pelajaran. Nilai yang diperoleh siswa di sekolah swasta mungkin lebih tinggi dibanding di sekolah negeri, sehingga perolehan nilai tersebut memperbesar peluang 
untuk dapat masuk ke Poltekkes Kemenkes Banten melalui jalur PMDP.

Upaya untuk menstandarkan kelembagaan sekolahnya saat penentuan calon mahasiswa yang masuk melalui jalur PMDP perlu dilakukan melalui hasil penilaian akreditasi institusi sekolahnnya.

Hasil uji statistic kai-skuer pada alpha 0,05 diperoleh nilai $\mathrm{p}$ $=0,387 \quad(\mathrm{p}>\alpha)$ yang berarti bahwa scara statistic tidak ada hubungan antara asal sekolah dengan perolehan prestasi semester I mahasiswa Poltekkes Kemenkes Banten yang masuk melalui jalur PMDP.

Hal ini kemungkinan terjadi karena sekolah telah dilakukan standarisasi melalui akreditasi sekolah baik negeri maupun swasta, sehingga asal sekolah tidak menjadi penentu dalam perolehan prestasibelajar mahasiswa, tetapi factor lain seperti minat, motivasi maupun gaya belajar lebih menentukan dalam perolehan prestasi belajar mahasiswa, ( Ahmadi, 2004). Teori ini sejalan dengan hasil penelitian yang diperoleh yang menjelaskan tidak ada hubungan antara asal sekolah dengan prestasi belajar

3. Hubungan jenis sekolah dengan prestasi belajar

Hasil penelitian menunjukkan bahwa prestasi belajar semester I, mahasiswa Poltekkes Kemenkes Banten yang masuk melalui jalur PMDP yang kurang baik, proporsinya lebih tinggi terjadi pada mahasiswa yang berasal dari jenis sekolah SMA (30,4\%) dibanding mahasiswa yang berasal dari sekolah Madrasah Aliyah(25\%).

Hasil uji statistic kai-skuer pada alpha 0,05 diperoleh nilai $\mathrm{p}$ $=1,00(p>\alpha)$ yang berarti bahwa scara statistic tidak ada hubungan antara jenis sekolah dengan perolehan prestasi semester I mahasiswa Poltekkes Kemenkes Banten yang masuk melalui jalur PMDP.

Hasil ini kemungkinan terjadi karena materi pelajaran yang diberikan di Madrasah Aliyah dan Sekolah Menengah Atas (SMA) tidak banyak memiliki perbedaan, sehingga saat mereka masuk semester I di Poltekkes Kemenkes 
Banten dan mengikuti materi kuliah memiliki kemampuan adaptasi yang relative sama. Gambaran ini terlihat mahasiswa yang memiliki prestasi yang kurang baik proporsinya relative sama antara mahasiswa yang berasal dari MA dan SMA, sehingga jenis sekolah tidak berhubungan dengan perolehan prestasi mahasiswa.

4. Hubungan jenis kelamin dengan prestasi belajar

Hasil penelitian menunjukkan bahwa prestasi belajar semester I, mahasiswa Poltekkes Kemenkes Banten yang masuk melalui jalur PMDP yang kurang baik, proporsinya lebih tinggi terjadi pada mahasiswa yang berjenis kelamin laki-laki $\quad(55,6 \%) \quad$ dibanding mahasiswa yang berjenis kelamin perempuan $(25,5 \%)$.

Gambaran ini kemungkinan terjadi karena perempuan pada umumnya cenderung lebih rajin dan lebih rapi dalam mengelola kegiatan, sehingga pada saat mengikuti proses belajar mahasiswa perempuan rajin dan saat menghadapi ujian akan lebih siap dibanding mahasiswa laki-laki. Kesiapan ini akan berpengaruh juga terhadap perolehan nilai dan perolehan prestasi mahasiswa.

Hasil uji statistic kai-skuer pada alpha 0,05 diperoleh nilai $\mathrm{p}=$ $0,156(p>\alpha)$ yang berarti bahwa scara statistic tidak ada hubungan antara jenis kelamin dengan perolehan prestasi semester I mahasiswa Poltekkes Kemenkes Banten yang masuk melalui jalur PMDP.

Walaupun ditemukan adanya perbedaan proporsi laki -laki dan perempuan dalam perolehan prestasi, namun ternyata factor jenis kelamin tidak menunjukan adanya hubungan terhadap perolehan prestasi. Keadaan ini mungkin disebabkan jenis kelamin bukan merupakan factor yang penting dalam menentukan prestasi.

Faktor yang menentukan terhadap prestasi mahasiswa antara lain factor potensi intelegensi, minat, motivasi, dan lingkungan belajar. Menyadari akan hal ini, maka guna meningkatkan prestasi mahasiswa perlu dikembangkan minat dan motivasi mahasiswa untuk belajar melalui kegiatan layanan bimbingan 
mahasiswa maupun penyediaan lingkungan belajar yang kondusif guna mendukung proses belajar mengajar yang baik.

\section{Simpulan}

Dari hasil penelitian yang telah penulis uraikan pada bagian terdahulu, dapat penulis simpulkan sebagai berikut :

1. Sebagian besar mahasiswa semester I yang masuk melalui jalur PMDP memiliki prestasi belajar yang baik (70\%), sementara sebagian kecil lainnya memperoleh prestasi belajar kurang baik (30\%)

2. Sebagian besar mahasiswa semester I yang masuk melalui jalur PMDP berasal dari sekolah negeri $(76,7 \%)$.

3. Hampir seluruhnya mahasiswa semester I yang masuk melalui jalur PMDP berasal dari jenis sekolah SMA $(93,4 \%)$

4. Sebagian besar mahasiswa semester I yang masuk melalui jalur PMDP berjenis kelamin perempuan $(85 \%)$

5. Tidak ada hubungan antara asal sekolah, jenis sekolah dan jenis kelamin dengan perolehan prestasi belajar mahasiswa semester satu.

\section{Saran}

1. Perlu terus dikembangkan rekruitmen mahasiswa baru melalui Jalur PMDP, antara lain menambahkan kriteria calon mahasiswa yang masuk melalui jalur PMDP, bukan hanya nilai yang diperoleh, tetapi juga memiliki peringkat prestasi akademik di kelasnya masuk ranking 1 sampai 5

2. Perlu dikembangkan minat dan motivasi mahasiswa untuk belajar melalui kegiatan layanan bimbingan mahasiswa maupun penyediaan lingkungan belajar yang kondusif guna mendukung proses belajar mengajar yang baik

3. Perlunya melakukan telaahan lebih lanjut pada mahasiswa yang memperoleh IP semester I dibawah 3,00 terhadap perolehan nilai pada waktu belajar di SMA serta lembaga sekolah SMA asal mahasiswa tersebut 


\section{DaftarPustaka}

Modul

Bhisma Murti, Prinsip dan metode riset epidemiologi, Gajahmada University Press, Jogjakarta, 2005

Departemen Kesehatan RI - WHO, Pencegahan dan penanggulangan penyakit demam berdarah dengue, Jakarta 2003

Surveilans, Jakarta 2004

James Chin, Manual pemberantasan penyakit menular,Infomedika, Jakarta, 2009

Kementerian Kesehatan RI, Modul Pelatihan Penanggulangan Penyakit Demam Berdarah Dengue, Jakarta, 2011

Departemen kesehatan RI, Pedoman Umum kegiatan surveilans, Jakarta 2000 